\title{
Evaluation of the Mechanical Properties of Polypropylene-Aluminum-Dross Composite
}

\author{
S. O. Adeosun, ${ }^{1}$ M. A. Usman, ${ }^{2}$ W. A. Ayoola, ${ }^{1}$ and I. O. Sekunowo ${ }^{1}$ \\ ${ }^{1}$ Department of Metallurgical and Materials Engineering, University of Lagos, Lagos 101017, Nigeria \\ ${ }^{2}$ Department of Chemical Engineering, University of Lagos, Lagos 101017, Nigeria
}

Correspondence should be addressed to M. A. Usman, mawwal04@yahoo.com

Received 11 January 2012; Accepted 13 February 2012

Academic Editor: Y. Kissin

Copyright $(2012$ S. O. Adeosun et al. This is an open access article distributed under the Creative Commons Attribution License, which permits unrestricted use, distribution, and reproduction in any medium, provided the original work is properly cited.

\begin{abstract}
Aluminum (Al) dross is a hazardous waste from the secondary smelting of aluminium industries, and safe disposal of this waste is a big challenge to these industries. Dumping of this waste is an environmental hazard to plants, animals, and even human beings. This study is aimed at improving the mechanical properties of polypropylene (PP) by adding Al dross in $2-50 \mathrm{wt} \%$ for particle sizes $53 \mu \mathrm{m}$ and $150 \mu \mathrm{m}$. PP-Al-dross composite samples were cast, and ultimate tensile strength (UTS), impact resistance (IR), water absorption (WA), and density (D) tests were carried out. The results obtained show that UTS improved by $68 \%$ (at $15 \mathrm{wt} \%$ $\mathrm{Al}$-dross addition), $\mathrm{D}$ increased by $54 \%$ (at $50 \mathrm{wt} \% \mathrm{Al}$-dross addition), and WA by 500\% (at $8 \mathrm{wt} \%$ Al-dross addition) over the convectional PP. The impact resistance of the composite was found to be the same (68 J) with that of conventional PP at $15 \mathrm{wt} \%$ $\mathrm{Al}$ dross.
\end{abstract}

\section{Introduction}

Aluminum (Al) drosses (white and black) are residues from primary and secondary aluminum production formed on the surface of molten $\mathrm{Al}$ that is exposed to furnace atmosphere during fusion processing. The dross is usually a mixture of free $\mathrm{Al}$ metal and nonmetallic substances such as aluminium oxide, nitride, and carbide; salts; metal oxides [1]. Disposal and recycling of dross is a worldwide problem. Majority of dross is disposed of in landfill sites, which is likely to result in leaking of toxic metal ions into the ground water causing serious pollution problems. In addition to this, when aluminium dross comes in contact with water it emits harmful gases such as $\mathrm{NH}_{3}, \mathrm{CH}_{4}, \mathrm{PH}_{3}, \mathrm{H}_{2}$, and $\mathrm{H}_{2} \mathrm{~S}$ [2]. When the dross particles are allowed to escape into the atmosphere, inhalation can cause health problems such as Alzheimer's disease, silicosis, and bronchitis.

The challenge posed by aluminium dross to the environment has continued to engage the attention of researchers over the years. Efforts are geared towards putting this otherwise hazardous waste to productive use. For example, it has been used as reinforcement for aluminium-matrix [3], as raw material for refractories [4], and as additive in cement production [5]. It has also been used in the synthesis of adsorbent and catalytic materials such as alumina and zeolites [6-13].

Polypropylene (PP) is a commodity polymer that has found wide range of applications in the packaging, textile, automobile, and furniture industries because of its good processbility, recyclability and low cost [14-16]. It has limited use as engineering thermoplastic due to its low strength, low modulus, and high notch sensitivity. To address this limitation, PP has been reinforced with rigid inorganic particles to enhance its strength and rigidity [17-24]. Reuse of $\mathrm{Al}$ dross as dispersed particles in polypropylene matrix would not only reduce the cost of LDPE composite but also solve the environmental consequence of dumping $\mathrm{Al}$ dross.

The aim of this study therefore was to investigate the suitability of reinforcing PP with Al dross from secondary smelting process and evaluate the mechanical properties of the resultant $\mathrm{PP} / \mathrm{Al}$ dross composite.

\section{Experimental Methodology}

The lumps of aluminium dross used in this study were obtained from Aluminium Rolling Mills Ota, Nigeria, and their chemical composition is displayed in Table 1. 
TABLE 1: Chemical composition of aluminium dross.

\begin{tabular}{lccccccccc}
\hline Constituents & $\mathrm{SiO}_{2}$ & $\mathrm{CaO}$ & $\mathrm{Na}_{2} \mathrm{O}$ & $\mathrm{Al}_{2} \mathrm{O}_{3}$ & $\mathrm{Fe}_{2} \mathrm{O}_{3}$ & $\mathrm{MgO}$ & $\mathrm{SO}_{3}$ & $\mathrm{~K}_{2} \mathrm{O}$ & $\mathrm{Al}_{\mathrm{metal}}$ \\
\hline Composition $\%$ & 7.15 & 0.07 & 0.06 & 63.84 & 0.03 & 0.04 & 0.03 & 0.01 & 28.77 \\
\hline
\end{tabular}

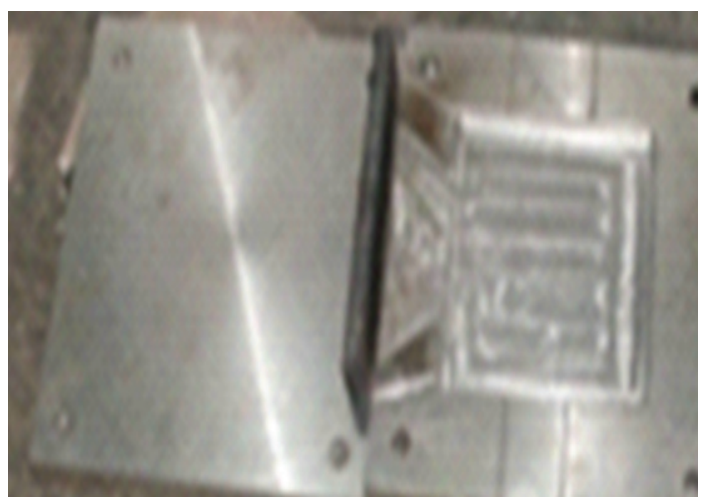

(a)

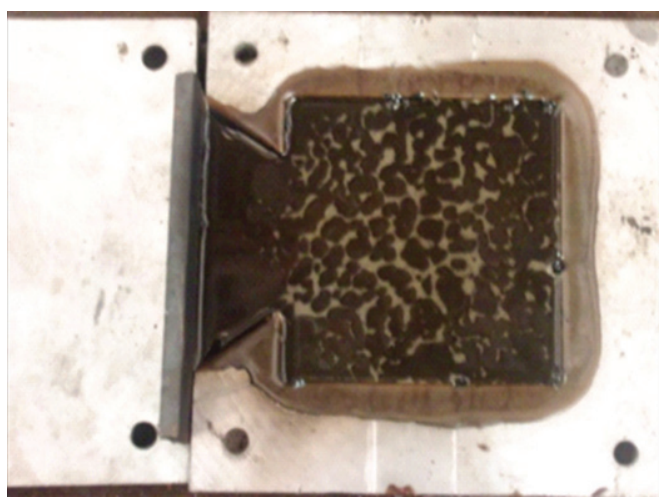

(b)

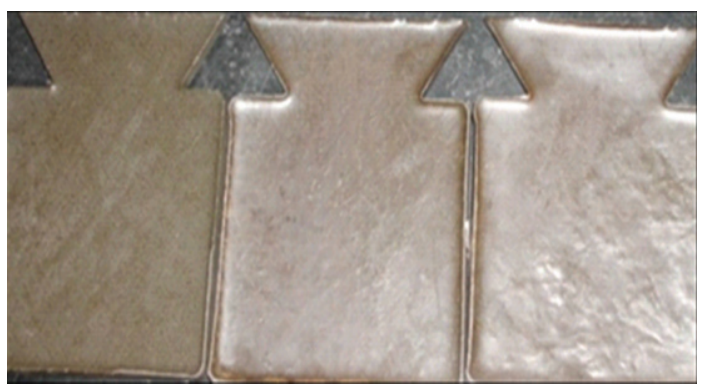

(c)

FIgURE 1: (a) Metal mould, (b) molten PP/Al dross composite solidifying in mould cavity, (c) solid PP/Al dross composite samples.

The Al dross lumps were ground and sieved into $53 \mu \mathrm{m}$ and $150 \mu$ sized particles. The masses of Al dross used are 2, $8,10,15,20,25,30,40$, and 50 wt percent while the balanced is that of PP. The measurement was done using an electronic digital scale on a basis of $300 \mathrm{~g}$ for the two particle sizes and the mixes.

The domestic camp gas was adapted as the melting furnace for the PP and the melting crucible was left to dry before the measured polypropylene was poured into it. The crucible and its content were heated up to molten state $\left(176^{\circ} \mathrm{C}\right)$ while stirring with the aid of the mixing rod for homogenous distribution of heat round the circumference of the crucible. When PP had been fully liquefied, the Al dross was poured into the molten PP and mixing was done thoroughly using the rod stirrer. The mixture was then heated up for another twenty seconds (to avoid burning into ashes) before pouring into the metal mould (see Figure 1). The pouring was done from one side of the mould at a fast rate and the container was held close to the mould during pouring. The cast composite samples on cooling have a dimension of $137 \times 137 \times 10 \mathrm{~mm}$.

The densities of the cast samples were obtained after fettling by weighing each sample on the digital weighing scale to obtain the mass $(m)$. The volume of water used was measured as $V_{1}$ then the sample was placed into the water, and the new volume was measured as $V_{2}$, hence the final volume $(v)$ of water used was determined and densities $(\rho)$ were calculated using the ratio of mass $(m)$ to volume $(v)$.

Water absorption samples were cut into sizes suitable for cylinder used for the water absorption process, weighed dried, $W_{1}$ at first instance. Subsequently, samples were then weighed after every $24 \mathrm{hrs}$ for a total of $168 \mathrm{hrs}$ to obtain the new sample weights $W_{2}$. The percentage weight gained was calculated as ratio of $\left(W_{2}-W_{1}\right)$ to $W_{1}$.

The tensile test specimens were machined (see Figure 2) and test was carried out using Hounsfield Tensometer tensile test machine. The test specimen was secured firmly between the gaps of the tensometer which was loaded mechanically until it was stressed to fracture. The test was carried out at a strain rate of $4.7 \times 10^{-2} \mathrm{~S}^{-1}$.

Impact resistance of the composites was carried out. Each sample was machined to the required specimen size; length of $100 \mathrm{~mm}$ and height of $8 \mathrm{~mm}, 6 \mathrm{~mm}$ thick and a V-notch at the centre of the specimen with depth of $2 \mathrm{~mm}$.

Scanning electron microscopy of the samples was carried out. The samples were cut into small bits required by the SEM machine; $1 \mathrm{~cm}$ by $1 \mathrm{~cm}$. Variable current (VP) was used because the samples are not electrically conducting. The 


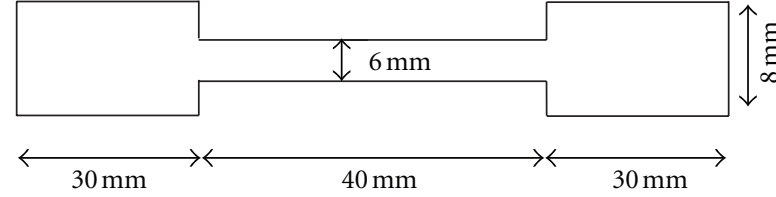

Figure 2: Tensile test specimen for PP-Al-dross composite.

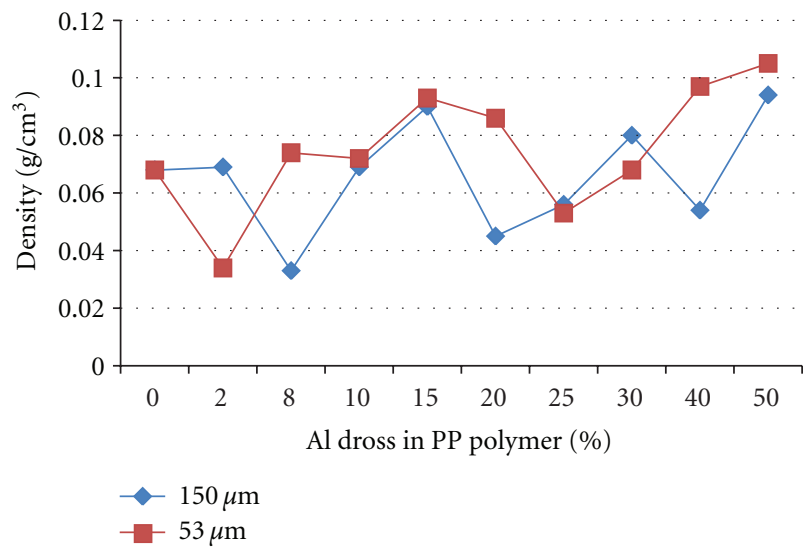

FIGURE 3: Density of polypropylene aluminum dross composite.

variable current makes the image clearer and works between pressures 10-200 $\mathrm{Pa}$. High vacuum could have been used, but it is restricted to only electrically conducting materials and works at pressures much higher than the VP. The pressure target was set to $50 \mathrm{~Pa}$.

\section{Results and Discussion}

3.1. Density. But for $53 \mu \mathrm{m} \mathrm{Al}$ dross size particle at $2 \mathrm{wt} \%$ dross addition, the composite density decline from $0.068 \mathrm{~g} /$ $\mathrm{cm}^{3}$ to $0.033 \mathrm{~g} / \mathrm{cm}^{3}$ and gained significant weight at $15 \mathrm{wt} \%$ dross addition $\left(0.093 \mathrm{~g} / \mathrm{cm}^{3}\right)$. Between 15 and $25 \mathrm{wt}$. percent dross additions, there was a decline to $0.052 \mathrm{~g} / \mathrm{cm}^{3}$. Increment in dross addition further increased the density to $0.105 \mathrm{~g} / \mathrm{cm}^{3}$ at $50 \mathrm{wt} \%$ dross content. For $150 \mu \mathrm{m}$ dross particle size, the density pattern of PP-Al-dross composite is sinusoidal. The density increases slightly with $2 \mathrm{wt} \%$ dross addition and declines from about $0.068 \mathrm{~g} / \mathrm{cm}^{3}$ to $0.033 \mathrm{~g} / \mathrm{cm}^{3}$ at $8 \mathrm{wt} \%$ dross addition. Between 8 and $15 \mathrm{wt} \%$ dross addition, the material gained in density to $0.09 \mathrm{~g} / \mathrm{cm}^{3}$, decreased to $0.045 \mathrm{~g} / \mathrm{cm}^{3}$ at $20 \mathrm{wt} \%$, rose to $0.08 \mathrm{~g} / \mathrm{cm}^{3}$ at $30 \mathrm{wt} \%$, fell to $0.055 \mathrm{~g} / \mathrm{cm}^{3}$ at $40 \mathrm{wt} \%$ and attained $0.095 \mathrm{~g} / \mathrm{cm}^{3}$ at $50 \mathrm{wt} \%$ dross content (see Figure 3).

3.2. Water Absorption. For water absorption tendencies, the PP-Al-dross composite initially absorbed water up to $0.01 \mathrm{wt} \%$ at 40 hours soak time and thereafter remained steady and uniform throughout the test period. Between 2 and $8 \mathrm{wt} \%$ dross addition, the composite absorbed water within 70 hours of soak time in similar fashion to pure PP matrix, and this response remained constant till 120 hours (0.01 wt $\%$ ) before it rose to $0.06 \mathrm{wt} \%$ at $8 \mathrm{wt} \%$ dross addition

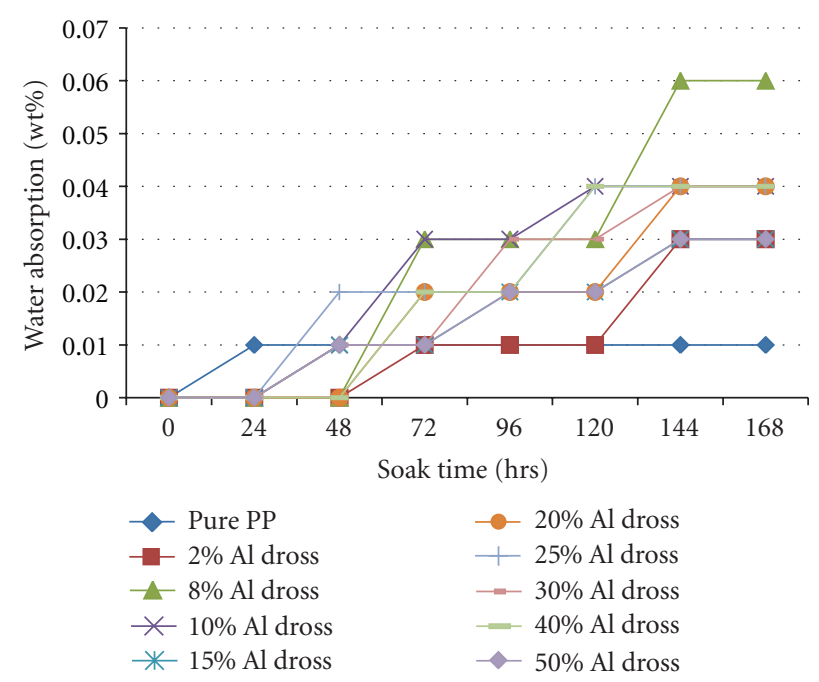

(a)

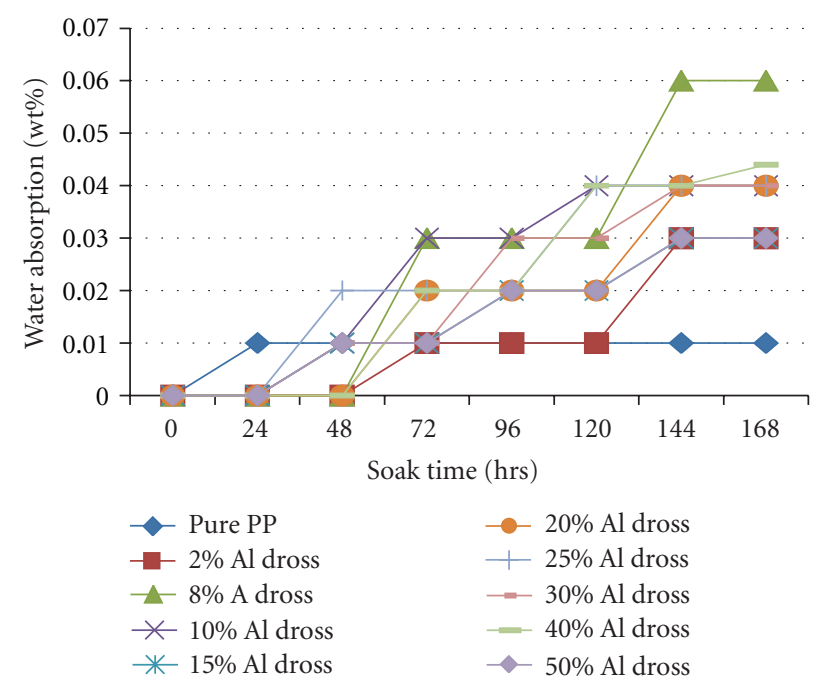

(b)

FIGURE 4: (a) Water absorption responses of polypropylene-aluminum-dross (53 micrometer) composite. (b) Water absorption responses of polypropylene-aluminum-dross (153 micrometer) composites.

between 140-168 hours soak time. As the Al-dross content in the PP matrix increases, the water absorption propensity decreases, and this fluctuates between 0.03 and $0.04 \mathrm{wt} \%$ for $10-40 \mathrm{wt} \% \mathrm{Al}$ dross and $0.03 \mathrm{wt} \%$ at $50 \mathrm{wt} \% \mathrm{Al}$-dross additions after 168 hours of soaking (see Figure 4(a)).

The water absorption potential of PP-Al-dross composite increases with its time of soaking in water at $2 \mathrm{wt} \% \mathrm{Al}-$ dross addition to give a maximum of $0.09 \mathrm{wt} \%$ between 140 and 168 hours. Between 8 and $20 \mathrm{wt} \%$ Al-dross additions the water absorption fluctuates between 0.03 and $0.04 \mathrm{wt} \%$ maximum. However, the PP composite absorbed more water at $25 \mathrm{wt} \% \mathrm{Al}$ dross content to give $0.06 \mathrm{wt} \%$ maximum between 140 and 168 hours soak time. Thereafter, it decreases to $0.02 \mathrm{wt} \%$ at $40 \mathrm{wt} \% \mathrm{Al}$ dross and rises again to $0.04 \mathrm{wt}$ at $50 \mathrm{wt} \% \mathrm{Al}$-dross addition (see Figure 4(b)). 


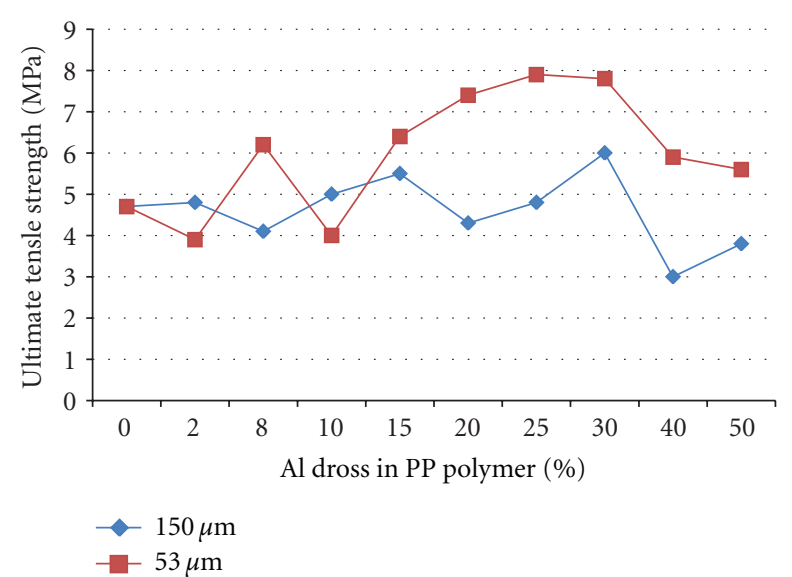

FIGURE 5: Ultimate tensile strength of polypropylene aluminum composite.

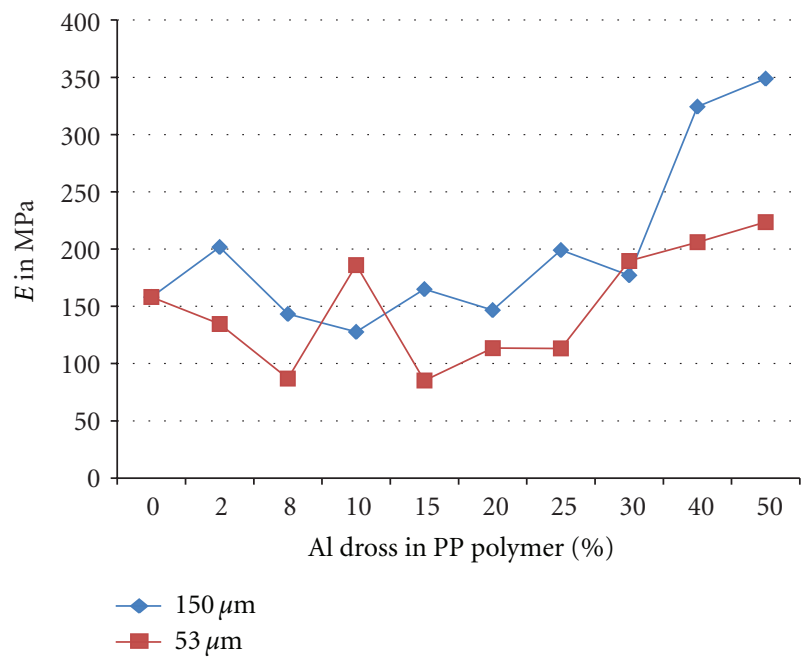

FIGURE 6: Young's modulus (E) of polypropylene-aluminum composite.

3.3. Ultimate Tensile Strengths. The ultimate tensile strengths of the PP improved significantly with the additions of $150 \mu \mathrm{m}$ particle-sized aluminium dross at 10, 15, and 30\% (5, 5.5, $6 \mathrm{MPa}$ ) with peak value of $6 \mathrm{MPa}$. For $53 \mu \mathrm{m}$ particle-sized aluminium dross addition improvements in UTS occurred at $8,15-50 \% \mathrm{Al}$ dross over the pure PP matrix. However, the peak value of $8 \mathrm{MPa}$ occurred at $25 \% \mathrm{Al}$-dross content (see Figure 5). The improvements in tensile strengths of the composites are due to good interfacial bonding and the presence of agglomerate particles [21]. The decline in strength in some composite samples over the pure PP matrix can be attributed to poor interfacial adhesion between the hydrophilic filler and the hydrophobic polymer matrix which hinders proper load transfer between filler and matrix. The weak bonding between the hydrophilic filler and the hydrophobic matrix polymer obstructs stress propagation and causes the tensile strength to decrease as the filler loading increases [21]. Further smaller size filler gives a superior strength result as smaller filler size with higher surface area

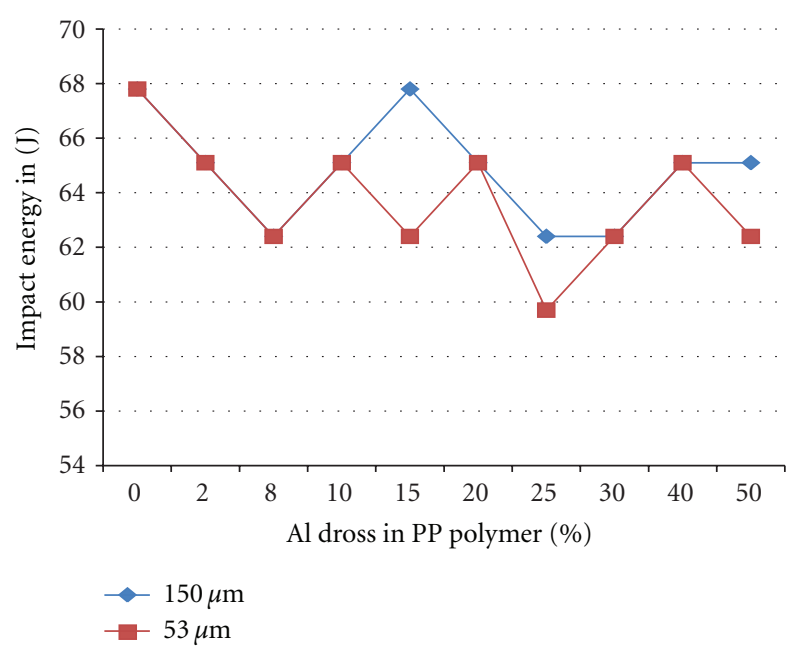

FIGURE 7: Impact energy of polypropylene-aluminum-composite.

gives better adhesion with matrix, which may be attributed to a better distribution of particles in PP [21].

3.4. Young's Modulus. Young's modulus $(E)$ of the PP material is enhanced at 2, 25, 40, and $50 \%$ dross (200, 200, 325, 350, MPa) contents for $150 \mu \mathrm{m}$ aluminium-dross particle size, while for $53 \mu \mathrm{m} \mathrm{Al-dross} \mathrm{particles} \mathrm{size,} \mathrm{the}$ composite rigidity is superior at $10,30,40$, and $50 \% \mathrm{Al}$ dross additions (180, 180, 205, $225 \mathrm{MPa}$ ) (see Figure 6). Filler with stiffness higher than that of the matrix may increase the modulus of the composites. The increase in tensile modulus with the increase of $\mathrm{Al}$ dross particles addition at the wt percents indicated above shows that PP has inherent stiffness of the filler [22]. Thus there is good transfer of the elastic deformation between filler and matrix materials without interface fracture. Tensile modulus is known to be a less sensitive variation of interfacial adhesion than the tensile strength which is strongly associated with interfacial failure behaviour [23]. Increase in tensile modulus of some composite samples is attributed to better distribution of $\mathrm{Al}$ dross filler in the matrix for both filler sizes. The higher surface area of filler gives better adhesion in composite, thus forming a stiffer material which is attributed to higher modulus [22].

3.5. Impact Energy Resistance. The impact energy resistance of PP is not enhanced with the introduction of $150 \mu \mathrm{m}$ sized $\mathrm{Al}$-dross filler, except at $15 \%$ filler addition where the impact energy resistance of $68 \mathrm{~J}$ same as the pure PP is obtained. The resistances produced at other filler additions are inferior to that of the pure PP matrix. This trend is comparably replicated with the use of $53 \mu \mathrm{m}$ particle-sized $\mathrm{Al}$-dross in the polymer where resistances are below that of pure PP matrix (68 J). At 2, 10, 20, and $40 \% \mathrm{Al}$ dross content the resistance of $65 \mathrm{~J}$ is obtained in the composites (see Figure 7). The poor interfacial bonding between the filler and the matrix polymer causes microcracks to occur at the point of impact, which causes the cracks to easily 


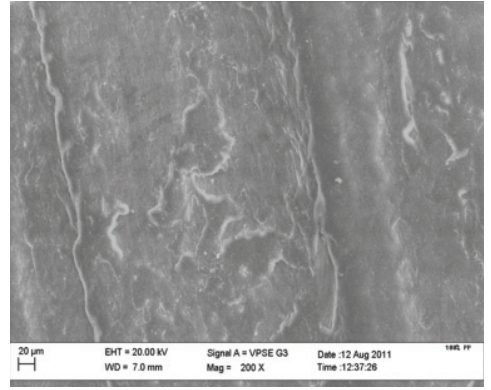

(a)

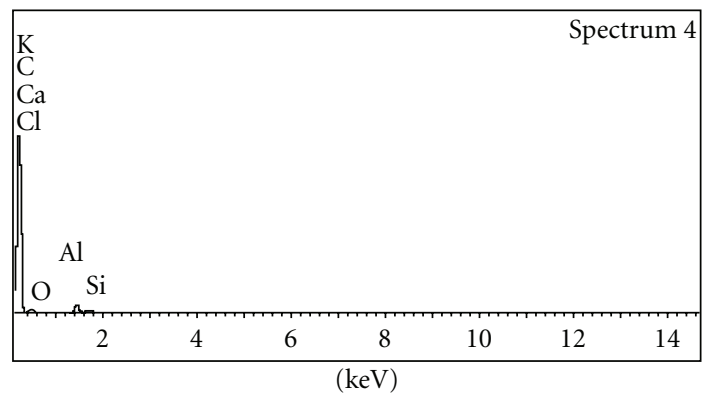

(b)

FIGURE 8: Pure polypropylene matrix characterisation, (a) SEM microstructure, (b) EDS chart.

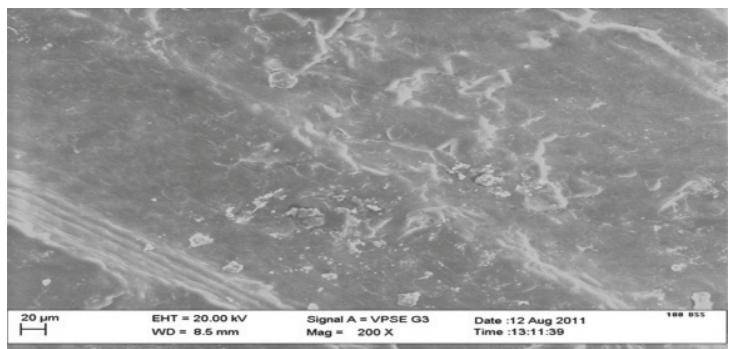

(a)

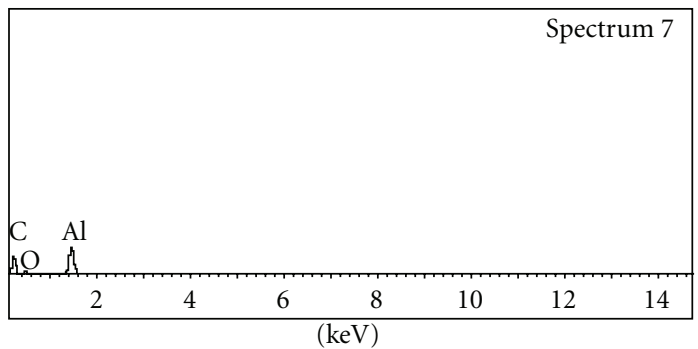

(b)

FIGURE 9: Polypropylene-Al-dross composite (98\% PP FOR $150 \mu \mathrm{m})$ matrix characterisation, (a) SEM microstructure, (b) EDS chart.

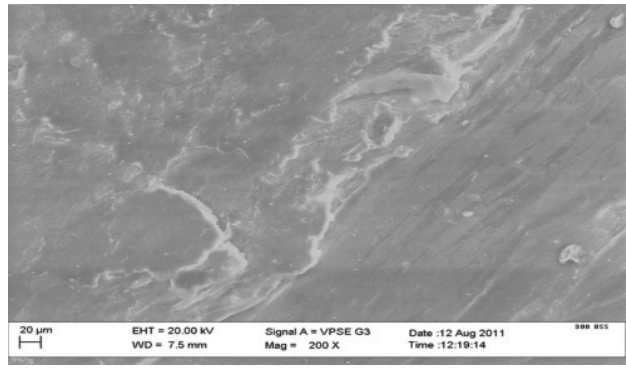

(a)

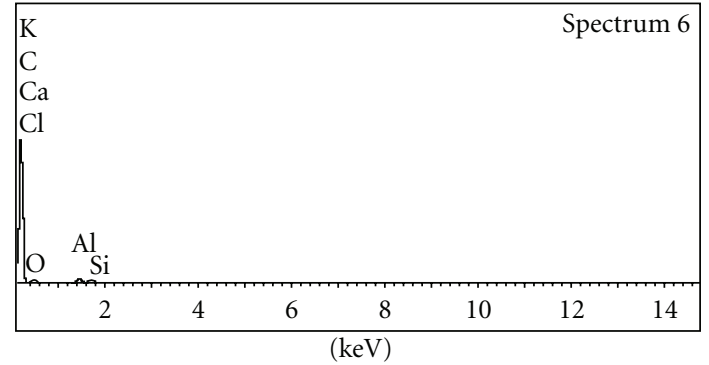

(b)

FIGURE 10: Polypropylene-Al-dross composite (98\% PP FOR $53 \mu \mathrm{m}$ ) matrix characterisation, (a) SEM microstructure, (b) EDS chart.

propagate in the composite [22]. These microcracks are responsible for the decreased in impact strength resistance of the composites. The increase in the amount of filler increased the interfacial regions, thus exaggerating the weakening of the resulting composite to crack propagation. Addition of filler inhibits polymer mobility, thereby lowering the ability of the system to absorb energy during fracture propagation. The size and dispersion of filler particles in the matrix can affect the composite properties. Small, well-dispersed particles generally give better properties [24]. Small particles can block crack propagation, resulting in impact toughening. However, it is often difficult to disperse very fine particles because of their tendency to agglomerate.

3.6. SEM and EDX Results of PP-Al-Dross Composite. The morphology of pure PP sample consists of the matrix phase and the white particles distribution. The structure is that of a hill and trough-like matrix (see Figure 8) and the EDX pattern revealed very low amount of elemental $\mathrm{Al}$, oxygen, and $\mathrm{Si}$ but high in $\mathrm{K}, \mathrm{Ca}$, and $\mathrm{C}$. The introduced coarse $(150 \mu \mathrm{m}) \mathrm{Al}$-dross particles are found dispersed in the matrix with the absence of hill and trough-like depression and absence of elements like $\mathrm{K}, \mathrm{Ca}$, and $\mathrm{C}$ as shown by the EDX result (see Figure 9). However, fine particles of the filler show better wetting of the particles and matrix as shown in Figure 10 with high presence of elemental $\mathrm{K}, \mathrm{Ca}$, and $\mathrm{C}$ as in pure $\mathrm{PP}$ while low in elemental $\mathrm{Al}$, oxygen, and $\mathrm{Si}$. Carbon is seen as the element with the highest peak with the presence some amount of oxygen and minute amount of aluminum. The finer the grain size, the higher the oxygen content and the lower the aluminum content. SEM microstructure of selected composite samples showed that poor adhesion in PP 
composites results in low impact strength. The interphase in PP-Al-dross composites that was formed effectively increased the tensile strength, but it is too weak thereby lowering the ability of the system to absorb energy during fracture propagation from the matrix to the filler. Thus, there is no improvement in impact strength.

\section{Conclusion}

There is a general enhancement of desirable mechanical properties when aluminum dross was added to polypropylene at different percentages. The better strengthening effect of the $\mathrm{Al}$ dross can be attributed to the better interfacial bond between the $\mathrm{Al}$ dross particles and the polypropylene matrix with the finer grain size $(53 \mu \mathrm{m})$ as revealed by the tensile test study. The best toughness and impact strength was obtained with the coarse grains $(150 \mu \mathrm{m})$ which can be attributed to the smaller surface area of the coarse grains. To obtain an optimum property of impact, tensile strength, and toughness, the percentage of $\mathrm{Al}$ dross to be used is $15 \% \mathrm{Al}$ dross addition for a grain size of $150 \mu \mathrm{m}$ and/or $20 \% \mathrm{Al}$-dross addition for a finer grain size of $53 \mu \mathrm{m}$. This study shows that $\mathrm{Al}$ dross is suitable for reinforcing PP and that it is a veritable way of addressing the environmental challenge posed by $\mathrm{Al}$ dross.

\section{References}

[1] O. Manfredi, W. Wuth, and I. Bohlinger, "Characterizing the physical and chemical properties of aluminum dross," JOM, vol. 49, no. 11, pp. 48-51, 1997.

[2] T. W. Unger and M. Beckmann, "Salt slag processing for recycling, light metals," in TMS Annual Meeting, E. R. Cutshall, Ed., pp. 1159-1162, San Diego, Calif, USA, 1992.

[3] V. M. Kevorkijan, "The quality of aluminum dross particles and cost-effective reinforcement for structural aluminumbased composites," Composites Science and Technology, vol. 59, no. 11, pp. 1745-1751, 1999.

[4] H. N. Yoshimura, A. P. Abreu, A. L. Molisani, A. C. de Camargo, J. C. S. Portela, and N. E. Narita, "Evaluation of aluminum dross waste as raw material for refractories," Ceramics International, vol. 34, no. 3, pp. 581-591, 2008.

[5] R. Kikuchi, "Recycling of municipal solid waste for cement production: pilot-scale test for transforming incineration ash of solid waste into cement clinker," Resources, Conservation and Recycling, vol. 31, no. 2, pp. 137-147, 2001.

[6] S. J. Yoo, H. S. Yoon, H. D. Jang et al., "Synthesis of aluminum isopropoxide from aluminum dross," Korean Journal of Chemical Engineering, vol. 23, no. 4, pp. 683-687, 2006.

[7] B. Dash, B. R. Das, B. C. Tripathy, I. N. Bhattacharya, and S. C. Das, "Acid dissolution of alumina from waste aluminium dross," Hydrometallurgy, vol. 92, no. 1-2, pp. 48-53, 2008.

[8] B. R. Das, B. Dash, B. C. Tripathy, I. N. Bhattacharya, and S. C. Das, "Production of $\eta$-alumina from waste aluminium dross," Minerals Engineering, vol. 20, no. 3, pp. 252-258, 2007.

[9] B. Lucheva, T. Tsonev, and R. Petkov, "Non-waste aluminium dross recycling," Journal of the University of Chemical Technology and Metallurgy, vol. 40, no. 4, pp. 335-338, 2005.

[10] N. Murayama, K. Arimura, N. Okajima, and J. Shibata, "Effect of structure-directing agent on $\mathrm{AlPO}_{4}-\mathrm{n}$ synthesis from aluminum dross," International Journal of Mineral Processing, vol. 93, no. 2, pp. 110-114, 2009.

[11] N. Murayama, N. Okajima, S. Yamaoka, H. Yamamoto, and J. Shibata, "Hydrothermal synthesis of $\mathrm{AlPO}_{4}-5$ type zeolitic materials by using aluminum dross as a raw material," Journal of the European Ceramic Society, vol. 26, no. 4-5, pp. 459-462, 2006.

[12] J. Kim, K. Biswas, K.-W. Jhon, S.-Y. Jeong, and W.-S. Ahn, "Synthesis of $\mathrm{AlPO}_{4}-5$ and CrAPO-5 using aluminum dross," Journal of Hazardous Materials, vol. 169, no. 1-3, pp. 919-925, 2009.

[13] M. Fang, H. Du, W. Xu, X. Meng, and W. Pang, "Microwave preparation of molecular sieve $\mathrm{AlPO}_{4}-5$ with nanometer sizes," Microporous Materials, vol. 9, no. 1-2, pp. 59-61, 1997.

[14] J. Z. Liang, "Toughening and reinforcing in rigid inorganic particulate filled poly(propylene): a review," Journal of Applied Polymer Science, vol. 83, no. 7, pp. 1547-1555, 2002.

[15] S. M. Zebarjad, R. Bagheri, A. Lazzeri, and S. Serajzadeh, "Fracture behaviour of isotactic polypropylene under static loading condition," Materials and Design, vol. 24, no. 2, pp. 105-109, 2003.

[16] B. Alcock, N. O. Cabrera, N. M. Barkoula, J. Loos, and T. Peijs, "The mechanical properties of unidirectional all-polypropylene composites," Composites Part A, vol. 37, no. 5, pp. 716-726, 2006.

[17] K. Yang, Q. Yang, G. Li, Y. Zhang, and P. Zhang, "Mechanical properties and morphologies of polypropylene/single-filler or hybrid-filler calcium carbonate composites," Polymer Engineering and Science, vol. 47, no. 2, pp. 95-102, 2007.

[18] J. Cho, M. S. Joshi, and C. T. Sun, "Effect of inclusion size on mechanical properties of polymeric composites with micro and nano particles," Composites Science and Technology, vol. 66, no. 13, pp. 1941-1952, 2006.

[19] Y. W. Leong, M. B. Abu Bakar, Z. A. M. Ishak, A. Ariffin, and B. Pukanszky, "Comparison of the mechanical properties and interfacial interactions between talc, kaolin, and calcium carbonate filled polypropylene composites," Journal of Applied Polymer Science, vol. 91, no. 5, pp. 3315-3326, 2004.

[20] Y. Zheng, Z. Shen, C. Cai, S. Ma, and Y. Xing, "The reuse of nonmetals recycled from waste printed circuit boards as reinforcing fillers in the polypropylene composites," Journal of Hazardous Materials, vol. 163, no. 2-3, pp. 600-606, 2009.

[21] H. S. Yang, H. J. Kim, J. Son, H. J. Park, B. J. Lee, and T. S. Hwang, "Rice-husk flour filled polypropylene composites; mechanical and morphological study," Composite Structures, vol. 63, no. 3-4, pp. 305-312, 2004.

[22] H. D. Rozman, G. B. Peng, and Z. A. M. Ishak, "The effect of compounding techniques on the mechanical properties of oil palm empty fruit bunch-polypropylene composites," Journal of Applied Polymer Science, vol. 70, no. 13, pp. 2647-2655, 1998.

[23] T. T. L. Doan, S. L. Gao, and E. Mäder, "Jute/polypropylene composites I. Effect of matrix modification," Composites Science and Technology, vol. 66, no. 7-8, pp. 952-963, 2006.

[24] T. Inoue and T. Suzuki, "Selective cross linking reaction in polymer blends-the effects of the cross linking of dispersed EPDM in particles on the impact behaviour of PP/EPDM blends," Journal of Applied Polymer, vol. 56, no. 9, pp. 1113-1125, 1995. 

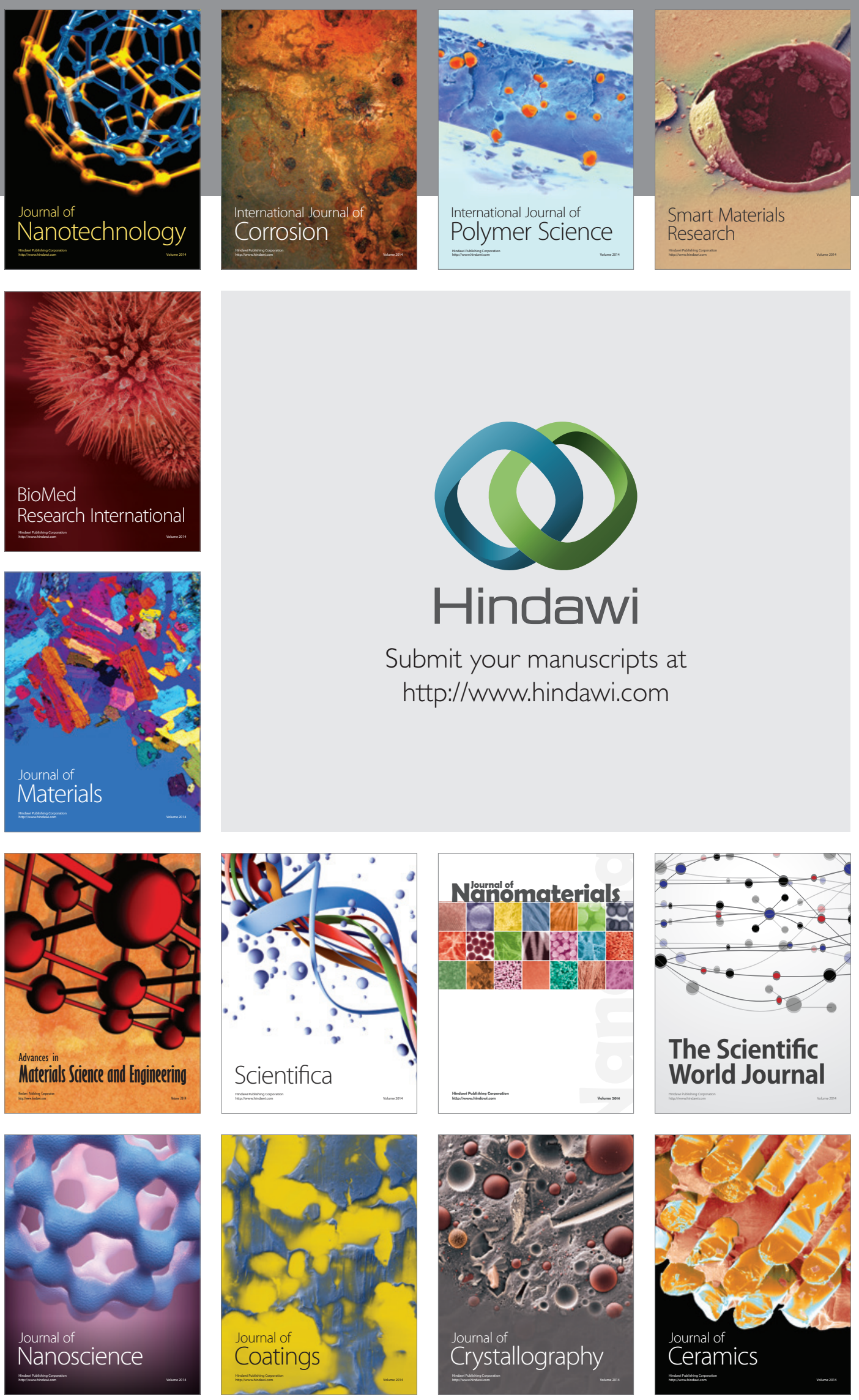

The Scientific World Journal

Submit your manuscripts at

http://www.hindawi.com

\section{World Journal}

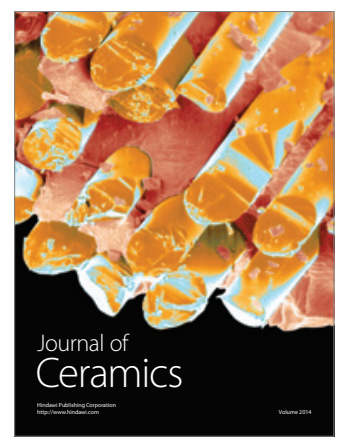

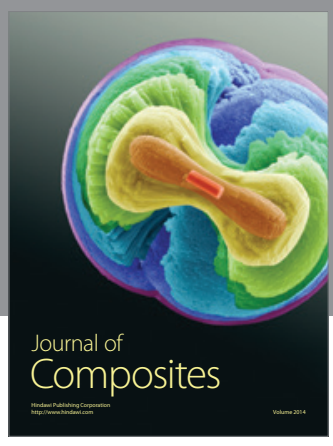
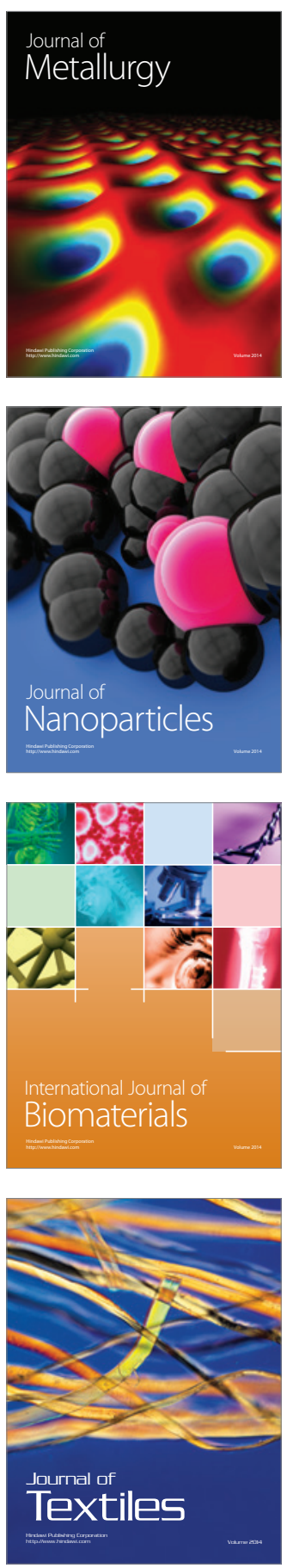